\title{
Pengembangan Modul Transformasi Berbasis CORE (Connecting, Organizing, Reflecting, Extending)
}

\author{
Rahmatina ${ }^{1}$, Laila Maharani, Abi Fadila, Bambang Sri Anggoro \\ ${ }^{1}$ Universitas Islam Negeri Raden Intan Lampung \\ 1rahmatina1702@gmail.com
}

\begin{tabular}{l}
\hline \hline Article Info \\
\hline Article history: \\
Received June $25^{\text {th }}, 2020$ \\
Revised July $30^{\text {th }}, 2020$ \\
Accepted Dec $28^{\text {th }}, 2020$ \\
\hline
\end{tabular}

Keywords:

Development;

Modules;

CORE

This study aims to produce teaching materials in the form of CORE-based modules on geometry transformation materials and to determine the responses of students, educators to the modules developed and to determine the effectiveness of CORE-based modules on geometry transformation material. This research method is Research and Development $(R \& D)$ using the ADDIE model which consists of the stages Analysis, Design, Development, Implementation, Evaluation. Based on the result of the validation of the material expert and the module media are stated with the "proper" criteria. Student responses on a small scale and large scale (field), as well as educator responses to modules with criteria of attractiviness aspects "very interesting". While the responses of educators to the modules developed obtained an average score of 4,42 with the criteria of attractiveness aspects "very interesting". The results of the assessment of the effectiveness test obtained an N-Gain score of 0,694 with "moderate" qualifications. So, teaching material in the form of CORE-based mathematics learning modules (Connecting, Organizing, Reflecting, Extending) on geometry transformation material is declared feasible, interesting, and effective to be used as teaching material in the learning process.

Kata Kunci:

Pengembangan;

Modul;

CORE

\section{Abstrak}

Penelitian ini bertujuan untuk menghasilkan bahan ajar yang berupa modul berbasis CORE pada materi transformasi geometri dan untuk mengetahui respon peserta didik, pendidik serta untuk mengetahui efektivitas modul berbasis CORE pada materi transformasi geometri. Metode penelitian ini adalah Research and Development (R\&D) menggunakan model 
ADDIE yang terdiri dari tahapan Analysis, Design, Development, Implementation, Evaluation. Berdasarkan data hasil validasi ahli materi dan media modul dinyatakan dengan kriteria "layak". Respon peserta didik pada skala kecil dan skala besar (lapangan), serta respon pendidik terhadap modul dengan kriteria aspek kemenarikan "sangat menarik". Hasil penilaian uji efektivitas memperoleh skor $N$ - Gain sebesar 0,694 dengan kualifikasi "sedang". Jadi bahan ajar berupa modul pembelajaran matematika berbasis CORE (Connecting, Organizing, Reflecting, Extending) pada materi transformasi geometri dinyatakan layak, menarik, dan efektif untuk digunakan sebagai bahan ajar dalam proses pembelajaran.

\section{PENDAHULUAN}

Pendidikan berdasarkan UU SISDIKNAS yang ada pada bab I pasal 1 yakni "Pendidikan ialah usaha sadar dan terencana untuk mewujudkan situasi belajar serta menciptakan proses pembelajaran supaya peserta didik lebih aktif dalam mengembangkan kemampuannya dalam bidang teknologi, sains maupun pendidikan (Departemen Pendidikan Nasional, 2012). Salah satu ilmu yang mengenai pendidikan ialah ilmu matematika. Matematika adalah ilmu yang bersifat universal yang dikenalkan sejak sekolah dasar (SD) sampai dengan jenjang perguruan tinggi. Ilmu yang harus ada pada setiap pendidikan baik formal maupun non formal dan harus mempunyai fasilitas media pembelajaran yang cukup baik sehingga proses belajar mengajar dapat terealisasikan sesuai dengan yang diharapkan (Supriadi, 2015). Ilmu hitung atau lebih dikenal ilmu matematika memiliki peranan sangat penting sebagai dasar logika atau penalaran yang digunakan dalam pelajaran lainnya (Nugroho, Putra, Putra, \& Syazali, 2017).

Pelajaran matematika pada tingkat pendidikan dasar dan menengah adalah mata pelajaran yang masih dianggap sulit oleh peserta didik sehingga banyak peserta didik yang tidak menyukainya. Banyak faktor yang membuat peserta didik tidak menyukai mata pelajaran matematika salah satunya cara seorang pendidik dalam menyampaikan materi masih 
banyak menggunakan model konvensional dan proses pembelajaran yang dilaksanakan di sekolah masih memakai bahan ajar berupa buku yang belum diperbaharui, sehingga pada proses pembelajaran peserta didik hanya terfokus pada seorang pendidik dan peserta didik tidak diberi kesempatan untuk berpikir secara mandiri. Hal ini juga menjadi tantangan bagi pendidik bagaimana cara mengubah pola pikir peserta didik bahwa mata pelajaran matematika itu tidak sulit dan mudah untuk dipahami.

Bagian yang sangat penting dalam pembelajaran ialah bahan ajar (Khasanah \& Fadila, 2018). Departemen Pendidikan Nasional mengungkapkan bahan ajar adalah serangkaian teori yang diatur secara terperinci sehingga demikian dapat menciptakan suasana belajar yang lebih menarik bagi peserta didik (Departemen Pendidikan Nasional, 2008). Salah satu bahan ajar yang dapat dikembangkan adalah Modul Pembelajaran. Modul pembelajaran adalah bahan ajar yang disusun secara sistematis dan menarik agar peserta didik dapat belajar secara mandiri tanpa dan atau dengan bimbingan pendidik untuk mencapai kompetensi yang diharapkan (Devi, Suyatna, Abdurahman, \& Ertikanto, 2017).

Berdasarkan hasil pra penelitian yang dilaksanakan, disimpulkan bahwa peserta didik masih sulit untuk mencerna dan belajar transformasi geometri, apabila kegiatan proses belajar mengajar terbatas. Misalnya, bahan ajar yang digunakan berupa Lembar Kerja Peserta Didik (LKPD) dan buku cetak. Peserta didik memerlukan modul yang lebih menarik yang bisa dipadupadankan dengan model pembelajaran, sedangkan pendidik masih belum maksimal dalam memanfaatkan model, metode yang bisa digunakan dalam proses pembelajaran. Pendidik masih lebih senang menggunakan metode maupun model konvensional seperti metode ceramah.

Seorang pendidik juga harus mampu menciptakan suasana yang mampu membangun semangat belajar dari peserta didik. Proses pembelajaran matematika yang baik adalah pendidik harus bisa menerapkan suasana yang dapat membuat peserta didik antusias terhadap pembelajaran matematika. Peranan pendidik hanyalah bersifat fasilitator dan memiliki kewajiban dalam upaya peningkatkan kualitas pembelajaran sehingga hasil belajar peserta didik lebih maksimal. Pendidik dituntut 
114 | Rahmatina, Maharani, Fadila, dan Anggoro: Pengembangan Modul Transformasi ...

selalu berinovasi dalam melaksanakan proses pembelajaran (Azizah, Mariani, \& Rochmad, 2012). Pendidik bisa berinovasi melalui model pembelajaran salah satunya model pembelajaran Connecting, Organizing, Reflecting, Extending. CORE yaitu model pembelajaran yang mudah di pahami, sehingga peserta didik mampu mengembangkan ilmu pengetahuan yang dimilikinya dengan caranya sendiri (Azizah et al., 2012).

Model pembelajaran CORE dapat membantu peserta didik dalam membangun pengetahuannya sendiri serta dipadukan dengan pendapat peserta didik lainnya, menciptakan dan menjelaskan ide-ide yang dimilikinya ke sesama teman. Dengan demikian, pembelajaran matematika dengan menggunakan modul berbasis model CORE dapat membantu peserta didik melatih dan mengembangkan kemampuannya sendiri dalam belajar terutama dalam memahami materi yang disampaikan. Sehingga diharapkan pula dengan penggunaan modul yang berbasis model CORE ini dapat merubah paradigma peserta didik bahwa matematika itu sulit untuk dipahami dan dimengerti. Penelitian ini dilakukan untuk mengembangkan modul matematika berbasis CORE dan mengetahui keefektifan dari bahan ajar tersebut.

\section{METODE PENELITIAN}

Metode penelitian dan pengembangan atau Research and Development (R\&D) adalah prosedur yang digunakan pada penelitian ini (Sugiyono,2014). Penelitian ini dilakukan di SMA Muhammadiyah 01 Muaradua pada peserta didik kelas XI. Penelitian ini menggunakan model pengembangan ADDIE, meliputi: Analysis (Analisis), Design (Perencanaan), Development (Pengembangan), Implementation (Penerapan), dan Evaluation (Evaluasi).

Teknik pengumpulan data dalam penelitian pengembangan ini yaitu wawancara, angket (kuesioner), dan dokumentasi. Instrumen yang digunakan dalam penelitian ini adalah lembar angket validasi dan angket respon peserta didik. Semua instrumen ini akan didistribusikan selama proses penelitian kuesioner tes media diberikan kepada dua dosen ahli. 
Validasi modul matematika berbasis CORE ini dilakukan oleh 4 (empat) dosen matematika dari UIN Raden Intan Lampung. Ahli materi yaitu dua orang dosen, dan ahli media yaitu dua orang dosen. Selain itu, praktisi pendidikan akan menjadi validator, yaitu 2 (dua) orang guru SMA Muhammadiyah 01 Muaradua. Validator materi satu orang dan satu orang lagi adalah ahli media. Teknik analisis hasil validasi ahli dilakukan dengan angket penilaian, berdasarkan skala Likert yang terdiri dari 5 skala penilaian yang dengan memberi tanda ceklis pada kategori yang telah disediakan oleh peneliti digunakan untuk menganalisis kevalidan atau kelayakan media. Hasil validasi yang terkandung dalam lembar validasi modul akan dianalisis menggunakan rumus sebagai berikut (Putra \& Setiawati, 2018):

$$
\bar{x}=\frac{\sum_{i=1}^{n} x_{i}}{n}
$$

dengan:

$$
x_{i}=\frac{\text { Jumlah } \text { skor }}{\text { Skor maks }} \times 5
$$

Keterangan:

$\bar{x}=$ Rata-rata akhir

$x_{i}=$ Nilai uji angket tiap validator

$n=$ Banyaknya aspek butir soal

Selanjutnya hasil presentase validasi modul dapat dikelompokkan dalam kriteria interpretasi skor sesuai dengan skala Likert, sehingga akan didapatkan kesimpulan tentang kelayakan modul. Kriteria interpretasi sesuai dengan skala Likert disajikan pada Tabel 1.

Tabel 1 Kriteria Interpretasi Kelayakan

\begin{tabular}{cc}
\hline Kriteria Interpretasi & Penilaian \\
\hline Sangat Layak & $4,00<\mathrm{x} \geq 5,00$ \\
Layak & $3,00<\mathrm{x} \leq 4,00$ \\
Cukup Layak & $2,00<\mathrm{x} \leq 3,00$ \\
Tidak Layak & $1,00<\mathrm{x} \leq 2,00$ \\
Sangat Tidak Layak & $0<\mathrm{x} \leq 1,00$ \\
\hline
\end{tabular}


Berdasarkan Tabel 1, maka produk pengembangan akan berakhir saat skor penilaian terhadap modul ini telah memenuhi syarat kelayakan dengan tingkat kesesuaian materi dan desain, pada pokok bahasan transformasi geometri dikategorikan layak.

Peneliti membuat angket untuk mengetahui respon dari peserta didik dan pendidik yang berisi beberapa pertanyaan, yang dibuat berdasarkan skala Likert yang terdiri dari 5 skala penskoran dengan memberi tanda ceklis pada kategori yang telah disediakan oleh peneliti guna untuk menganalisis kevalidan atau kemenarikan media. Hasil angket respon peserta didik akan dianalisis menggunakan rumus rerata.

Tahap selanjutnya berdasarkan skala Likert yang terdiri 5 skala penilaian yang digunakan untuk menganalisis kriteria interprestasi kemenarikan disajikan pada Tabel 2.

Tabel 2 Kriteria Interpretasi Kemenarikan

\begin{tabular}{cc}
\hline Kriteria interpretasi & Penilaian \\
\hline Sangat Menarik & $4,00<\mathrm{x} \geq 5,00$ \\
Menarik & $3,00<\mathrm{x} \leq 4,00$ \\
Cukup Menarik & $2,00<\mathrm{x} \leq 3,00$ \\
Tidak Menarik & $1,00<\mathrm{x} \leq 2,00$ \\
Sangat tidak Menarik & $0<\mathrm{x} \leq 1,00$ \\
\hline
\end{tabular}

Tingkat keefektifan didapat dari hasil pre-test dan post-test pada hasil belajar peserta didik. Perhitungan $N$-Gain digunakan untuk mengetahui peningkatan nilai pre-test dan post-test, dengan rumus:

$$
g=\frac{S_{\text {post-test }}-S_{\text {pre-test }}}{S_{\text {maks }}-S_{\text {pre-test }}}
$$

Keterangan:

$\begin{array}{ll}g & : N-\text { Gain } \\ S_{\text {post-test }} & : \text { Skor post-test } \\ S_{\text {pre-test }} & : \text { Skor pre-test } \\ S_{\text {maks }} & : \text { Skor maksimum }\end{array}$


Hasil perhitungan $N$-Gain diinterpretasikan dengan menggunakan klasifikasi Hake. Tingkat efektivitas berdasarkan rata-rata nilai $N$ - Gain (Hartati, 2016) dapat dilihat pada Tabel 3.

Tabel 3 Nilai Rata-Rata $\boldsymbol{N}$ - Gain dan Klasifikasinya

\begin{tabular}{ccc}
\hline Rata-rata $\boldsymbol{N}-$ Gain & Klasifikasinya & Tingkat Efektivitas \\
\hline$(\mathrm{g}) \geq 0,70$ & Tinggi & Efektivitas Tinggi \\
$0,30 \leq(\mathrm{g})<0,70$ & Sedang & Efektivitas Sedang \\
$(\mathrm{g})<0,30$ & Rendah & Efektivitas Rendah \\
\hline
\end{tabular}

\section{HASIL PENELITIAN DAN PEMBAHASAN}

Penelitian menghasilkan sebuah media pembelajaran sebagai bahan ajar yang berupa modul pembelajaran matematika berbasis CORE pada materi transformasi geometri. Uji kelayakan mendapatkan hasil validasi setelah melalui beberapa proses uji validasi. Tabulasi hasil validasi oleh ahli materi pada produk disajikan dalam bentuk diagram pada Gambar 1.

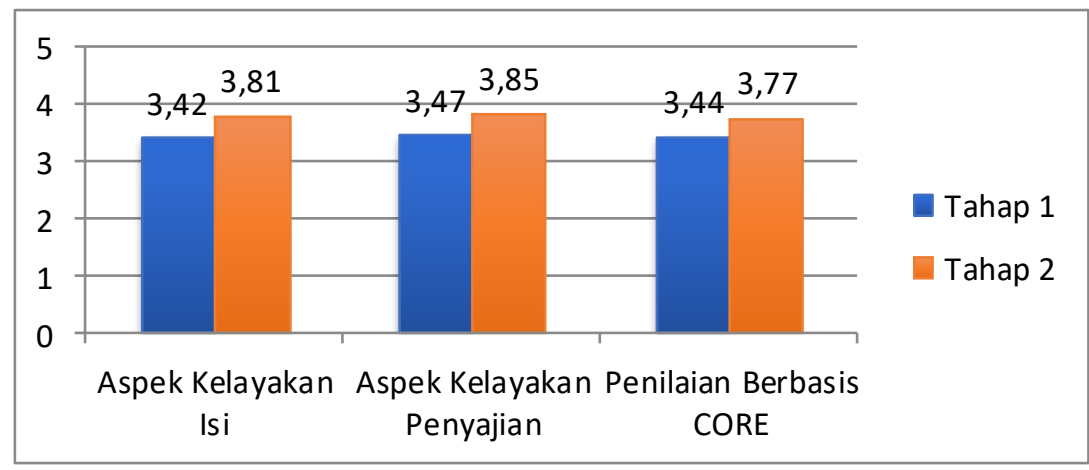

\section{Gambar 1 Grafik Perbandingan Hasil Validasi Ahli Materi Tahap 1 dan Tahap 2}

Pada produk awal diperoleh skor rata-rata 3,44 berdasarkan hasil validasi oleh ahli materi dengan kategori validasi "layak". Kemudian dilakukan validasi kembali setelah produk direvisi sehingga mendapat rata-rata 3,81 dengan kategori validasi "layak", terjadi peningkatan skor setelah produk direvisi. Grafik hasil validasi oleh ahli media pada produk dapat dilihat dalam diagram pada Gambar 2. 


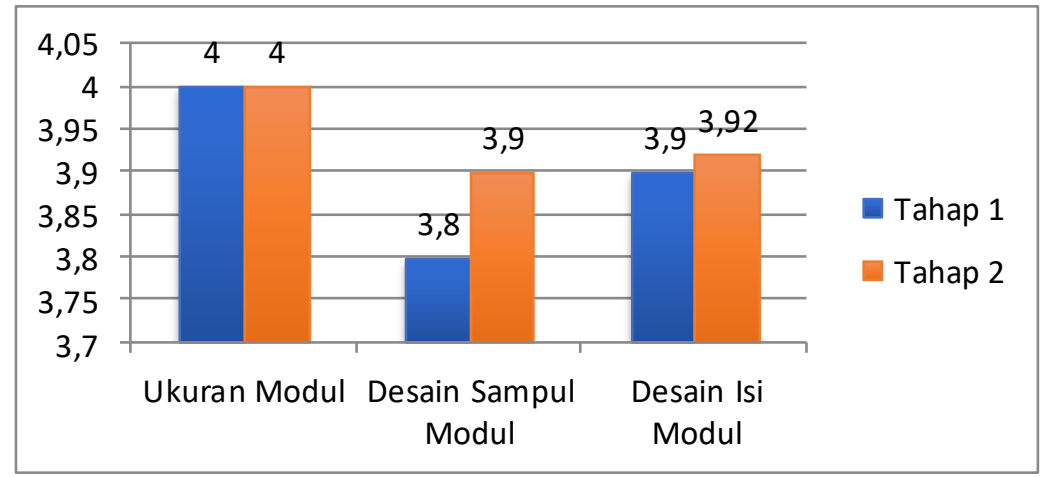

\section{Gambar 2 Grafik Perbandingan Hasil Validasi Ahli Media Tahap 1 dan Tahap 2}

Pada produk awal diperoleh rata-rata skor 3,90 berdasarkan hasil validasi oleh ahli media dengan kategori validasi "layak". Setelah produk direvisi dilakukan validasi kembali dan mendapat rata-rata skor 3,94 dengan kategori validasi "layak" peningkatan skor terjadi setelah produk direvisi. Uji coba produk dilakukan pada peserta didik di kelas XI SMA Muhammadiyah 01 Muaradua. Uji coba dilakukan pada 6 orang peserta didik untuk skala kecil dan 18 orang peserta didik untuk skala besar (lapangan) (Tegeh \& Kirna, 2013). Grafik hasil angket respon peserta ddik pada produk terlihat pada Gambar 3.

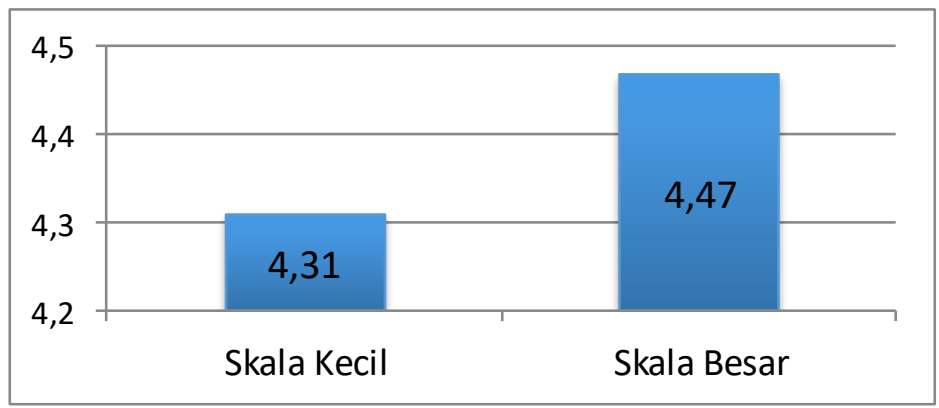

\section{Gambar 3 Grafik Perbandingan Uji Coba Skala Kecil dan Skala Besar (Lapangan)}

Terdapat perbedaan antara rata-rata nilai hasil uji coba untuk skala kecil dan skala besar (lapangan). Hasil rata-rata nilai untuk uji coba skala 
kecil mengalami peningkatan saat uji coba skala besar (lapangan). Adapun hasil yang didapat untuk uji skala kecil addalah 4,31 dengan kriteria "Sangat Menarik" dan untuk uji coba skala besar (lapangan) mendapat nilai 4,47 dengan kriteria "Sangat Menarik".

Setelah dilakukannya uji coba skala kecil dan skala besar (lapangan) selanjutnya peneliti melakukan uji coba kepada pendidik yaitu salah satu pendidik matematika SMA Muhammadiyah 01 Muaradua. Pada langkah ini pendidik dimintai untuk mengisi angket tentang daya kemenarikan bahan ajar yang telah dikembangkan. Hasil uji coba pendidik memperoleh nilai 4,42 dengan kriteria "Sangat Menarik". Hal ini berarti modul yang dikembangkan oleh peneliti layak dan sangat menarik digunakan sebagai alat bantu kegiatan pembelajaran matematika khususnya materi transformasi geometri kelas XI SMA/MA berdasarkan hasil yang telah diperoleh. Perhitungan $\mathrm{N}$-Gain digunakan untuk mengetahui peningkatan pre-test dan post-test. Pada Tabel 4 ditampilkan hasil perhitungan pre-test dan post-test.

Tabel 4 Hasil Perhitungan Pre-Test dan Post-Test

\begin{tabular}{lccccc}
\hline & N & $\begin{array}{c}\text { Skor } \\
\text { Ideal }\end{array}$ & $\begin{array}{c}\text { Skor } \\
\text { Minimum }\end{array}$ & $\begin{array}{c}\text { Skor } \\
\text { Maksimum }\end{array}$ & $\begin{array}{c}\text { Skor } \\
\text { Rata-Rata }\end{array}$ \\
\hline Pre-test & 32 & 100 & 30 & 70 & 57,78 \\
Post-test & 32 & 100 & 70 & 100 & 84,81 \\
\hline
\end{tabular}

Berdasarkan Tabel 4 dapat diketahui baik skor minimum maupun maksimum dan rata-rata pre-test dan post-test. Pada pre-test memperoleh skor minimum 30 dan skor maksimum 70 serta rata-rata skor 57,78 . Skor maksimum post-test 100, untuk skor minimum 70 dan rata-rata skor sebesar 84,81. Rekapitulasi nilai $N$-Gain dapat dilihat melalui Tabel 5.

Tabel 5.Rekapitulasi Nilai $N$-Gain

\begin{tabular}{cccc}
\hline $\mathrm{N}$ & Skor Min & Skor Maks & Skor Rata-rata \\
\hline 32 & 0,423 & 1,000 & 0,694 \\
\hline
\end{tabular}


Dari Tabel 5 berdasarkan data yang diperoleh kita dapat mengetahui skor minimum, skor maksimum, dan skor rata-rata $N$-Gain. Nilai minimum yang didapat dari pre-test dan post-test yaitu 0,423, sedangkan nilai maksimumnya adalah 1,000 . Hasil rata-rata $N$-Gain diperoleh nilai 0,694 dan termasuk dalam kategori "Sedang".

Tujuan dari penelitian ini adalah untuk menghasilkan sebuah produk berupa modul yang berbasis CORE pada materi transformasi geometri. Peneliti dalam penelitian ini telah melakukan validasi sebanyak 2 kali. Dalam tahap 1 validasi, validator ahli materi memberikan skor rata-rata 3,44 dengan kriteria "layak" berdasarkan aspek-aspek yang dinilai. Aspek tersebut yaitu kelayakan isi, kelayakan penyajian dan penilaian berbasis CORE. Adapun rata-rata skor yang diberikan validator ahli media adalah 3,90 kriteria "layak" dengan penilaian aspek ukuran modul, desain sampul (cover), dan desain isi modul. Produk direvisi setelah selesai validasi tahap 1 sesuai dengan saran dari setiap validator. Berdasarkan masukan dari validator terdapat beberapa hal yang harus diperbaiki seperti aspek materi dan aspek desain. Pada aspek materi, dilakukannya perbaikan pada gambar dan materi yang masih kurang. Perbaikan pada aspek desain dilakukan pada sampul depan modul,, ukuran kertas serta jenis huruf pada halaman.

Tahap selanjutnya adalah validasi yang ke 2 pada tahap ini terdapat peningkatan skor di berbagai aspek dikarenakan produk telah direvisi sesuai dengan saran dari para validator. Dalam validasi tahap 2, rata-rata skor yang diberikan validator ahli materi adalah 3,81 termasuk kategori "layak" berdasarkan aspek-aspek yang dinilai. Aspek tersebut terdiri dari kelayakan isi, kelayakan penyajian, serta penilaian berbasis CORE. Berdasarkan penilaian pada aspek ukuran modul, desain sampul modul (cover), dan desain isi modul, rata-rata skor yang diberikan validator ahli media yaitu 3,94 dengan kriteria "layak".

Setelah dilakukannya validasi, tahap selanjutnya adalah implementation (penerapan) yaitu melakukan uji coba skala kecil dan skala besar (lapangan) serta uji efektivitas. Uji coba skala kecil dan skala besar (lapangan) dilakukan peneliti untuk mengukur daya kemenarikan modul dengan melibatkan 6 dan 18 peserta didik kelas XI serta seorang 
pendidik SMA Muhammadiyah 01 Muaradua. Sampel dipilih secara purposive sampling berdasarkan nilai dari pendidik matematika. Peserta didik diberi angket oleh peneliti yang berisi pertanyaan dengan rentang nilai 1 sampai 5. Pada tes skala kecil diperoleh skor rata-rata dengan nilai 4,31 dengan kriteria "Sangat Menarik". Skor rata-rata yang diperoleh pada uji coba skala besar (lapangan) adalah 4,47 termasuk kategori "Sangat Menarik", serta skor rata-rata yang diperoleh dari respon pendidik ialah 4,42 dengan kriteria "Sangat Menarik". Peserta didik menanggapi positif untuk modul yang telah dikembangkan karena sebelumnya mereka hanya menggunakan buku cetak biasa dan LKPD sehingga saat pembelajaran kurang menarik dan membosankan. Adapun respon pendidik sangat luar biasa positif pada produk ini karena dapat digunakan sebagai alat bantu dalam kegiatan pembelajaran. Langkah selanjutnya peneliti melakukan uji efektivitas.

Uji efektivitas ini diperoleh dari pre-test dan post-test yang dilakukan oleh peneliti pada awal dan akhir pembelajaran terhadap peserta didik. Peneliti memberikan pertanyaan pre-test di awal pertemuan. Peserta didik menggunakan produk dalam bentuk modul yang dibuat oleh peneliti selama pembelajaran yang sedang berlangsung sebagai sumber belajar. Peserta didik diberikan post-test setelah mereka belajar dan memahami materi transformasi geometri dalam modul. Berdasarkan dari uji efektivitas diketahui bahwa nilai rata-rata $\mathrm{N}$-Gain termasuk dalam kategori sedang karena nilai berada pada kisaran $0,30 \leq(\mathrm{g})<0,70$. Hal ini menunjukkan bahwa modul yang dikembangkan mempunyai efektivitas yang sedang apabila diterapkan dalam pembelajaran.

Produk yang telah dikembangkan dalam penelitian ini memiliki kelebihan yaitu modul dibuat dengan tampilan yang menarik sehingga peserta didik lebih bersemangat untuk belajar. Produk dilengkapi dengan gambar-gambar yang berkaitan dengan materi transformasi geometri serta mempermudah peserta didik untuk memahami materi dengan menggunakan langkah-langkah CORE. Dalam modul terdapat berbagai contoh dan latihan soal yang akan membuat peserta didik berlatih kaerna jenis soal yang dikembangkan dalam modul ini bervariasi. 
Produk yang telah dikembangkan dalam penelitian ini memiliki kekurangan diantaranya materi dalam modul ini masih terbatas yaitu hanya materi transformasi geometri sehingga perlu dikembangkan lebih luas. Selain itu adanya beberapa gambar dalam modul berasal dari sumber sekunder yaitu situs internet, serta produk dicetak dengan menggunakan mesin cetak biasa sehingga produk yang diproduksi kurang maksimal.

\section{SIMPULAN}

Modul matematika berbasis CORE pada materi transformasi geometri dikembangkan dengan metode ADDIE yang meliputi tahaptahapan Analysis, Design, Development, Implementation, dan Evaluation. Hasil modul yang dikembangkan termasuk kriteria yang layak serta layak digunakan berdasarkan penilaian ahli materi dan ahli media. Adapun respon peserta didik dan pendidik memperoleh kriteria sangat menarik, baik pada saat uji coba skala kecil, skala besar (lapangan) maupun pada uji kemenarikan. Efektivitas penggunaan modul matematika berbasis CORE diperoleh nilai $\mathrm{N}$-Gain sebesar 0,694 dengan kategori sedang yang diterapkan selama proses pembelajaran. Artinya, modul yang dihasilkan efektif untuk digunakan dalam pembelajaran.

\section{DAFTAR PUSTAKA}

Azizah, L., Mariani, S., \& Rochmad, R. (2012). Pengembangan Perangkat Pembelajaran Model Core Bernuansa Konstruktivistik untuk Meningkatkan Kemampuan Koneksi Matematis. Unnes Journal of Mathematics Education Research, 1(2).

Departemen Pendidikan Nasional. (2008). Perangkat Pembelajaran KTSP SMA. Jakarta: Direktorat Pembinaan Sekolah Menengah Atas.

Departemen Pendidikan Nasional. (2012). Undang-Undang SISDIKNAS. Bandung: Fokusindo.

Devi, E. P., Suyatna, A., Abdurahman, \& Ertikanto, C. (2017). Efektivitas Modul dengan Model Inkuiri untuk Menumbuhkan Keterampilan Proses Sains Siswa Pada Materi Kalor. Jurnal Tadris: Keguruan Dan Ilmu Tarbiyah, 2(2).

Hartati, R. (2016). Peningkatan Aspek SikapLiterasi Sains Siswa SMP Melalui Penerapan Model Problem Based Learning Pada Pembelajaran IPA Terpadu. Edusain UIN Syarif Hidayatullah, 8(1). 
Khasanah, B. A., \& Fadila, A. (2018). Pengembangan LKPD Geometri Transformasi Dengan Motif Tapis Lampung. JURNAL E-DuMath, 4(2).

Nugroho, A. A., Putra, R. W. Y., Putra, F. G., \& Syazali, M. (2017). Pengembangan Blog Sebagai Media Pembelajaran Matematika. AlJabar: Jurnal Pendidikan Matematika, 8(2).

Putra, R. W. Y., \& Setiawati, N. (2018). Pengembangan Desain Didaktis Bahan Ajar Persamaan Garis Lurus. Jurnal Penelitian Dan Pembelajaran Matematika, 11(1).

Sugiyono. (2014). Metode Penelitian Pendidikan Pendekatan Kuantitatif, Kualitatif dan $R \& D$. Bandung: Alfabeta.

Supriadi, N. (2015). Mengembangkan Kemampuan Koneksi Matematis Melalui Buku Ajar Elektronik Interaktif (BAEI) yang Terintegrasi Nilai-Nilai Keislaman. Al-Jabar: Jurnal Pendidikan Matematika, $6(1)$.

Tegeh, I. M., \& Kirna, I. M. (2013). Pengembangan Bahan Ajar Metode Penelitian Pendidikan dengan Model ADDIE. Jurnal IKA, 11(1). 
124 | Rahmatina, Maharani, Fadila, dan Anggoro: Pengembangan Modul Transformasi ... 